INTERNATIONAL JOURNAL OF MULTIDisciplinARY RESEARCH AND ANALYSis

ISSN(print): 2643-9840, ISSN(online): 2643-9875

Volume 04 Issue 06 June 2021

DOI: 10.47191/ijmra/v4-i6-24, Impact Factor: 6.072

Page No.- $843-853$

\title{
The Effect of Price Perception and Game Features in Online Virtual Game Item Purchase Decisions
}

\author{
Eka Mayastika Sinaga \\ Sekolah Tinggi Ilmu Ekonomi Bina Karya
}

\begin{abstract}
This study tries to answer the research objectives, namely to find out how the influence of Price Perception and Game Features on Online Game Virtual Item Purchase Decisions. The results of hypothesis testing using multiple regression analysis with two independent variables and one dependent variable indicate that: The proposed $\mathrm{H} 1$ states that Price Perception has no effect on Online Game Virtual Item Purchase Decisions, it can be seen if the tcount value is 0.896 or less than ttable $(\alpha: 5 \%$, df : $37=$ 2.026192), in addition, the significance value is 0.376 or greater than the model significance value of 0.05 . Then $\mathrm{H} 1$ is rejected, meaning that this cannot affect the Online Game Item Virtual Purchase Decision. The proposed H2 states that Game Features have an effect on Online Game Virtual Item Purchase Decisions, it can be seen if the tcount value of 1.908 is smaller than ttable $(5 \%$, df : $37=2.026192$ ), but the significance value is 0.064 or greater than the value the significance of the model is 0.05 . Then $\mathrm{H} 2$ is rejected, meaning that this cannot affect the Online Game Item Virtual Purchase Decision. The proposed H3 states that Price Perception and Game Features simultaneously affect the Decision to Purchase Virtual Items Online Game, from table 4.12 the Fcount value is 4.751 or greater than the Ftable value ( $\alpha: 5 \%$, dk numerator :2, dk denominator : $39-2-1$, Ftable: 3.26), besides the significance value is 0.015 or less than the model significance (0.05), it can be concluded if $\mathrm{H} 3$ is accepted, meaning that Price Perception and Game Features simultaneously affect Virtual Purchase Decisions Online Game Items.
\end{abstract}

KEYWORDS: Price Perception, Game Features and Purchase Decision

\section{INTRODUCTION}

As we know the internet has become an inseparable part of human life today. The internet has always been used and has become an important need for business transactions, communication, entertainment facilities, and social interactions for its users. Online games are video games that can be run when a device is connected to the internet. The development of online games itself is quite rapid and popular because it can be accepted by all circles of children, teenagers and adults. Online games which were originally only available on large devices such as computers, consoles have now penetrated into mobile phones which make it easier for players to play online games so that the number of online game players is currently increasing and increasing because they can be played anywhere.

The game developed from the beginning where the graphics and gameplay created by a man named Alexander Shafto Douglas or Sandy, created graphic computer games when he was pursuing a degree in EDSAC computer at the University of Cambridge. This game was named "Tic-Tac-Toe" in 1952. Then in 1958, William Higinbotham was able to create his first video game called "Tennis for Two". Then continued in 1962, a new game was created. A student named Steve Russell managed to create the first interactive computer game which was named "SpaceWar". This game is played using a computer. Spacewar was one of the first digital computer video games. Meanwhile, in 1966 the first interactive television game was invented by Ralph Baer and the game was named Chase. Ralph Baer is a pioneer, inventor, as well as an engineer and is also known as the "Father of Video Games".

In recent years, several online games have attracted a lot of interest from various groups, by presenting an easy and interesting way of playing which makes some online games very popular in the community. In addition to finding the winners, online games also function as a means of making friends or gathering for the players.

Online games are starting to switch functions that were previously only as entertainment media, and in the millennial era where the majority of the people already have smartphones to support game applications with a large enough capacity, and with 


\section{The Effect of Price Perception and Game Features in Online Virtual Game Item Purchase Decisions}

the virtual selling feature of in-game items or transferring items they have to other players. , which is solely for the benefit and satisfaction of the users themselves.

Virtual items have become one of the important things in the game. Lin and Sun (2007) in Bastian (2015) describe there are two types of virtual items themselves, namely, functional properties that are useful for maximizing the ability of game characters to be competent and decorative properties that are useful for changing the visualization of characters in games.

There are three sources of income for publishers in the online game business according to Tunjungsari (2016), namely:

1) Pay-to-play, where players have to pay a certain amount of money every month to play. For example: Final Fantasy XIV: Realm Reborn, and World Of Warcraft: Shadowlands

2) Buy-to-play, where players have to pay to install the game and create an account with no monthly fees. For example: Grand Theft Auto V, FIFA, etc

3) Free-to-play, where players don't have to pay anything to play the game. For example: Point Blank, PUBGM, Mobile Legends, Home Scapes, Ragnarock M Eternal Love, etc.

Based on the online game revenue source, the publisher's income (companies that produce games) comes from virtual product sales, subscription fees, advertising, merchandise, auctions or trades between players, expansion packs or DLC, events or tournaments, TrialPay, and donations. Most online games in Indonesia use the free-to-play model and the largest online game revenue comes from selling virtual products or what is commonly known as micro-transactions. Along with the development of online games, micro-transactions or what can be called the purchase of in-game items are also growing rapidly. Purchase of ingame items on multiple players is very helpful in making online games easier.

Purchasing decisions according to Philip Kotler (2011) are all their experiences in learning, choosing, using, and even getting rid of products. The consumer buying decision process goes through six stages, namely: problem recognition, information search, evaluation of alternatives, purchase decisions, purchases, and post-purchase behavior.

\section{PROBLEM INTRODUCTION}

The buying process begins when the buyer becomes aware of a problem or need that is triggered by internal or external stimuli.

1. Information search

The first source of information where consumers are divided into 4 groups, namely:

a. Personal, including: Family, friends, neighbors, colleagues.

b. Commercial, including: Advertising, Web site, salesperson, dealer, packaging, display.

c. Public, including: Mass media, consumer rating organizations.

d. Experimental, including: Handling, inspection, use of the product.

2. Evaluation of alternatives

How consumers process competitive brand information and make final value judgments.

3. Purchase decision

In the evaluation stage, consumers form preferences between brands in a choice set. Consumers may also form an intention to buy the most preferred brand.

4. Purchase

In this stage, consumers carry out purchasing activities based on predetermined decisions to meet their needs.

5. Post-purchase behavior

After a purchase, consumers may experience conflict due to seeing certain worrying features or hearing favorable things about other brands and being wary of information that supports their decision.

There are several reasons players buy micro-transactions, one of which is that they want interesting items or rare items that only exist during that period. The rare item in question is a kind of virtual item that is traded by game developers with the aim of making a profit.

Game features according to Mullich (2018) are descriptive aspects of the design, art, audio, or technical abilities of games which are attractive to consumers or in this case players in buying virtual items. The features of this game have several aspects that exist in every game such as game mechanics, music, stories, player characters, online multiplayer mode features, level difficulty, to item inventory and the diversity of these items. Thus providing different characteristics in each game.

The games that exist today compete with each other to create interesting features, from the graphical interface, the presentation of stories, characters, to songs, which the game developers then package them as attractively as possible. Even now we have started a trend of games with increasingly varied graphical interfaces but with simple gameplay by presenting cool and funny characters to be sold to players as exclusive items for the players to collect. 


\section{The Effect of Price Perception and Game Features in Online Virtual Game Item Purchase Decisions}

The phenomenon or fact in this study is that along with the rapid emergence of online games, especially on smartphone devices, resulting in many users playing them and also among popular online game players such as Mobile Legends, there are those who have bought virtual items by spending a lot of money, starting from 6 million, 11 million until there are children who spend their parents' money up to 65 million rupiahs just to buy diamonds to buy skins in the game where diamonds and skins are items that at that time became contested items by the players, even though they know that the online game they are playing may close the server one day, especially the virtual item purchase system that uses the gacha system or known as a random draw system with uncertain prizes, still does not hinder their intention to buy virtual items for their favorite online games they are just for the sake of getting satisfaction and happiness also proud of the ego between players.

Therefore, based on the explanation that has been described above, the author is interested in conducting research with the title "The Influence of Price Perception and Game Features in Purchase Decisions of Virtual Online Game Items."

\section{A. Problem Formulation}

Based on the background of this research which has been described above, it can be defined the formulation of the problem in accordance with this research is as follows:

1. Does price perception affect the virtual purchase decision of online game items?

2. Do game features affect virtual purchase decisions for online game items?

3. Do price perceptions and game features simultaneously influence purchasing decisions for virtual online game items?

B. Purpose

In accordance with the formulation of the problem taken, the objectives of this study are as follows:

a. This study aims to determine whether price perception has an effect on purchasing decisions for virtual online game items.

b. To find out whether game features affect virtual purchasing decisions for online game items.

c. This study aims to determine whether the perception of price and game features simultaneously influence the decision to purchase virtual online game items.

\section{THEORETICAL BASIS}

\section{A. Consumer Behavior}

According to Tjiptono (2019), consumer behavior is a series of activities carried out by consumers in order to find solutions to their needs and desires. Meanwhile, consumer behavior according to Engel et al (2006) in Sangadji (2013) is an action that is directly involved in obtaining, consuming, and disposing of products/services, including the processes that precede and follow these actions. Meanwhile, consumer behavior according to Griffin (2005) in Sangadji (2013) are all activities, actions, and psychological processes that encourage these actions before buying, when buying, using, spending products and services after doing the things above or evaluating activities. .

\section{B. Purchase Decision}

Purchasing decisions according to Kotler (2011) are all their experiences in learning, choosing, using, and even getting rid of products. Meanwhile, according to Schiffman and Kanuk in Sangadji (2013) purchasing decisions define a decision as the selection of an action from two or more alternative choices. A consumer who wants to choose must have alternative choices. A decision without a choice is called a "Hobson choice".

Then according to Tjiptono (2012) purchase decision is a process where consumers recognize the problem, seek information about a particular product or brand and evaluate well each alternative can solve the problem, which then leads to a purchase decision.

Based on the above understanding, it can be concluded that the purchase decision is a decision-making process that begins with the introduction of the problem then evaluates it and decides the product that best suits the needs.

\section{Price Perception}

The word perception in the KBBI is a direct response (acceptance) of something, the process of a person knowing some things through his five senses. According to Kotler (2013), perception is where we select, organize, and interpret information input to create a meaningful picture of the world.

Meanwhile, according to Kotler and. Keller (2012), price is one element of the marketing mix that generates revenue, another element generates costs. According to Kotler and Armstrong (2012) price can be defined narrowly as the amount of 


\section{The Effect of Price Perception and Game Features in Online Virtual Game Item Purchase Decisions}

money charged for a product or service. Or it can be broadly defined as price as the amount of value that consumers exchange for the benefit of owning and using a product or service that allows the company to earn a reasonable profit by being paid for the customer value it creates. It can be concluded that the definition of price in online game items is the amount of money spent by players in buying an item in an online game.

Price perception according to Zeithmal in Kusdyah (2012) is a consumer assessment of the comparison of the amount of sacrifice with what will be obtained from products and services. Meanwhile, according to Kotler and Armstrong (2012) price perception is the value contained in a price related to the benefits of owning or using a product or service.

\section{Game Features}

Features according to Kotler (2012) are product characteristics that complement product functions. Meanwhile, according to Tjiptono, features are secondary or complementary characteristics of goods and services. Then according to Kotler \& Armstrong (2012) the notion of features as a competitive means to differentiate the company's products from competitors. Through features, companies can create product differentiation from competitors' products. Features are additional characteristics or characteristics that complement the basic benefits of a product. Features are optional or optional for consumers. When the main benefits are standard, features are often added. features can improve product quality if competitors don't have them.

In the Indonesian dictionary "Game" is defined as a game. The game is part of playing and playing is also part of the game both are interconnected. The game is a complex activity in which there are rules, play and culture.

A game is a system in which players engage in artificial conflict, here players interact with the system and conflict in the game is engineered or artificial, in the game there are rules that aim to limit player behavior and determine the game.

\section{RESEARCH METHODS}

\section{A. Scope of Research}

1. Research Location

This research will be conducted at the High School of Economics (STIE) Bina Karya Tebing Tinggi which is located on JI. Diponegoro (Simpang Rambung), Kec. Tebing Tinggi City, Kota Tebing - Tinggi, North Sumatra 20631.

2. Research Time This research will be conducted from May 2020 to June 2020.

\section{B. Types and Sources of Data}

1. Data Type

The type of data used is quantitative data, namely the type of data that can be measured or calculated directly as a variable number or number.

2. Data Source

The type of data used in this study is primary data, namely data obtained from respondents' answers to questions posed by researchers using questionnaires and interviews.

\section{DISCUSSION}

\section{Descriptive Analysis of Research Variables}

\section{Purchase Decision Variable (Y)}

It is known the number and percentage of respondents' answers regarding the Purchase Decision Variable $(\mathrm{Y})$ as presented in Table 1 below:

Table 1. Description of Respondents' Answer Score Regarding Purchase Decision Variables (Y)

\begin{tabular}{|c|c|c|c|c|c|}
\hline \multirow[t]{2}{*}{ Statement } & \multicolumn{5}{|l|}{ Answer } \\
\hline & SS & $S$ & KS & TS & STS \\
\hline $\begin{array}{l}\text { 1. I feel interested in making virtual } \\
\text { purchases of items in the games I } \\
\text { play. }\end{array}$ & $\begin{array}{l}8 \quad \text { orang } \\
(20,5 \%)\end{array}$ & $\begin{array}{l}16 \quad \text { orang } \\
(41,0 \%)\end{array}$ & $\begin{array}{l}10 \quad \text { orang } \\
(25,6 \%)\end{array}$ & $\begin{array}{l}4 \quad \text { orang } \\
(10,3 \%)\end{array}$ & 1 orang $(2,6 \%)$ \\
\hline
\end{tabular}


The Effect of Price Perception and Game Features in Online Virtual Game Item Purchase Decisions

\begin{tabular}{|c|c|c|c|c|c|}
\hline $\begin{array}{l}\text { 2. I bought virtual items because my } \\
\text { friends also bought virtual items in } \\
\text { the online games I played. }\end{array}$ & $\begin{array}{l}5 \quad \text { orang } \\
(12,8 \%)\end{array}$ & $\begin{array}{l}10 \quad \text { orang } \\
(25,6 \%)\end{array}$ & $\begin{array}{l}14 \text { orang } \\
(35,9 \%)\end{array}$ & $\begin{array}{l}6 \quad \text { orang } \\
(15,4 \%)\end{array}$ & 4 orang $(10,3 \%)$ \\
\hline $\begin{array}{l}\text { 3. I will suggest my friends to buy } \\
\text { virtual items to my friends who play } \\
\text { online games. }\end{array}$ & $\begin{array}{l}6 \quad \text { orang } \\
(15,4 \%)\end{array}$ & $\begin{array}{l}11 \quad \text { orang } \\
(28,2 \%)\end{array}$ & $\begin{array}{l}17 \text { orang } \\
(43,6 \%)\end{array}$ & $\begin{array}{l}5 \quad \text { orang } \\
(12,8 \%)\end{array}$ & - \\
\hline $\begin{array}{l}\text { 4. I am interested in buying virtual } \\
\text { items back in the near future. }\end{array}$ & $\begin{array}{l}5 \quad \text { orang } \\
(12,8 \%)\end{array}$ & $\begin{array}{l}13 \quad \text { orang } \\
(33,3 \%)\end{array}$ & $\begin{array}{l}11 \text { orang } \\
(28,2 \%)\end{array}$ & $\begin{array}{l}8 \quad \text { orang } \\
(20,5 \%)\end{array}$ & 2 orang $(5,1 \%)$ \\
\hline
\end{tabular}

Table 1 shows that the average respondents' answers are on the scale of agree and disagree with the average answer value of 3.39 (high). This shows that from the 4 measurement indicators of the Purchasing Decision Variable (Y) it can be concluded that the average score of the Purchasing Decision Variable (Y) is in the high category (Riduwan and Kuncoro, 2017).

\section{Price Perception Variable (X1)}

It is known the number and percentage of respondents' answers regarding the Price Perception variable as presented in Table 4.2 below:

Table 2. Description of Respondents' Answer Score Regarding Price Perception Variables (X1)

\begin{tabular}{|c|c|c|c|c|c|}
\hline \multirow[t]{2}{*}{ Statement } & \multicolumn{5}{|l|}{ Answer } \\
\hline & SS & $S$ & $\mathrm{KS}$ & TS & STS \\
\hline $\begin{array}{l}\text { 1. The virtual items I buy are worth the money I spend } \\
\text { on the online games I play. }\end{array}$ & $\begin{array}{l}6 \quad \text { orang } \\
(15,4 \%)\end{array}$ & $\begin{array}{l}22 \quad \text { orang } \\
(56,4 \%)\end{array}$ & $\begin{array}{l}9 \text { orang } \\
(23,1 \%)\end{array}$ & $\begin{array}{l}2 \text { orang } \\
(5,1 \%)\end{array}$ & - \\
\hline $\begin{array}{l}\text { 2. The virtual price of the item I bought is relatively } \\
\text { affordable for me. }\end{array}$ & $\begin{array}{l}12 \text { orang } \\
(30,8 \%)\end{array}$ & $\begin{array}{l}25 \quad \text { orang } \\
(64,1 \%)\end{array}$ & $\begin{array}{l}2 \\
(5,1 \%)\end{array}$ & - & - \\
\hline
\end{tabular}

Table 2 shows that the average respondents' answers are on the agree and strongly agree scale with the average answer value of 4.04 (high). This shows that from the 2 measurement indicators of the Price Perception variable (X1) it can be concluded that the average Price Perception variable (X1) is in the high category (Riduwan and Kuncoro, 2017).

\section{Game Feature Variables (X2)}

It is known the number and percentage of respondents' answers regarding the Game Features variable (X2) as presented in Table 3 below:

Table 3. Description of Respondents' Answer Score Regarding Game Feature

Variables (X2)

\begin{tabular}{|c|c|c|c|c|c|}
\hline \multirow[t]{2}{*}{ Statement } & \multicolumn{5}{|l|}{ Answer } \\
\hline & SS & S & $\mathrm{KS}$ & TS & STS \\
\hline $\begin{array}{l}\text { 1. The online games that I play have very diverse } \\
\text { features. }\end{array}$ & $\begin{array}{l}12 \text { orang } \\
(30,8 \%)\end{array}$ & $\begin{array}{l}25 \text { orang } \\
(64,1 \%)\end{array}$ & $\begin{array}{l}1 \text { orang } \\
(2,6 \%)\end{array}$ & $\begin{array}{l}1 \text { orang } \\
(2,6 \%)\end{array}$ & - \\
\hline 2. The online games I play have quality features & $\begin{array}{l}10 \text { orang } \\
(25,6 \%)\end{array}$ & $\begin{array}{l}22 \text { orang } \\
(56,4 \%)\end{array}$ & $\begin{array}{l}5 \quad \text { orang } \\
(12,8 \%)\end{array}$ & - & $\begin{array}{l}2 \text { orang } \\
(5,1 \%)\end{array}$ \\
\hline $\begin{array}{l}\text { 3. I feel that the features in online games are very } \\
\text { important to make the game more interesting }\end{array}$ & $\begin{array}{l}21 \text { orang } \\
(53,8 \%)\end{array}$ & $\begin{array}{l}16 \text { orang } \\
(41,0 \%)\end{array}$ & $\begin{array}{l}1 \text { orang } \\
(2,6 \%)\end{array}$ & $\begin{array}{l}1 \text { orang } \\
(2,6 \%)\end{array}$ & - \\
\hline $\begin{array}{l}\text { 4. The online games that I play have very complete } \\
\text { supporting features }\end{array}$ & $\begin{array}{l}10 \text { orang } \\
(25,6 \%)\end{array}$ & $\begin{array}{l}22 \text { orang } \\
(56,4 \%)\end{array}$ & $\begin{array}{l}5 \quad \text { orang } \\
(12,8 \%)\end{array}$ & $\begin{array}{l}2 \text { orang } \\
(5,1 \%)\end{array}$ & - \\
\hline
\end{tabular}

Table 3 shows that the average respondent's answers are on the agree and strongly agree scale with the average answer value of 4.17 (high). This shows that from the 4 measurement indicators for the Game Feature variable (X2), it can be concluded that the average Game Feature variable score (X2) is in the high category (Riduwan and Kuncoro, 2017).

\section{Classic assumption test}

The tests of classical assumptions with the SPSS 17.00 program carried out in this study include: 


\section{The Effect of Price Perception and Game Features in Online Virtual Game Item Purchase Decisions}

\section{Normality Test}

Normality test aims to test whether in the regression model, the confounding or residual variables have a normal distribution (Ghozali, 2016:154). Testing the normality of the data can be done using two methods, graphs and statistics. The normality test of the graph method uses a normal probability plot, while the statistical method normality test uses the one sample Kolmogorov Smirnov Test.

Table 4. One Sample Kolmogorov Smirnov Test

One-Sample Kolmogorov-Smirnov Test

\begin{tabular}{|ll|l|}
\hline & & Unstandardized Residual \\
\hline Normal Parameters ${ }^{\mathrm{a}, \mathrm{b}}$ & Mean & 39 \\
& Std. Deviation & .0000000 \\
& & 3.25086443 \\
Most Extreme Differences & Absolute & .117 \\
& Positive & .067 \\
& Negative & -.117 \\
Kolmogorov-Smirnov Z & & .732 \\
Asymp. Sig. (2-tailed) & & .657 \\
Monte Carlo Sig. (2-tailed) Sig. & $.692^{\mathrm{c}}$ \\
& 99\% Confidence Interval Lower Bound & .502 \\
& & Upper Bound \\
& & .883 \\
\hline
\end{tabular}
a. Test distribution is Normal.
b. Calculated from data.
c. Based on 39 sampled tables with starting seed 2000000.

From the output in table 4, it can be seen that the significance value (Monte Carlo Sig.) of all variables is 0.692 . If the significance is more than 0.05 , then the residual value is normal, so it can be concluded that all variables are normally distributed.

\section{Multicollinearity Test}

The multicollinearity test aims to determine whether there is a correlation between the independent variables in the regression model. The multicollinearity test in this study is seen from the tolerance value or variance inflation factor (VIF). The calculation of the tolerance value or VIF with the SPSS 17.00 program for windows can be seen in Table 5 below:

\section{Table 5. Multicollinearity Test Results}

\section{Coefficients $^{\mathrm{a}}$}

\begin{tabular}{|ll|l|l|}
\hline \multicolumn{2}{|l|}{ Model } & \multicolumn{2}{l|}{ Collinearity Statistics } \\
\cline { 2 - 4 } & (Constant) & & Volerance \\
\hline & PRICE PERCEPTION & .673 & \\
& FITUR GAME & .673 & 1.485 \\
\hline
\end{tabular}

a. Dependent Variable: BUYING DECISION

Based on table 5 it can be seen that the tolerance value of the Price Perception variable (X1) is 0.673, the Game Feature variable $(\mathrm{X} 2)$ is 0.673 , all of which are greater than 0.10 while the VIF value of the Price Perception variable $(\mathrm{X} 1)$ is 1.485 , the Feature variable Game (X2) is 1.485 where all of them are smaller than 10 . Based on the results of the above calculations, it can be seen that the tolerance value of all independent variables is greater than 0.10 and the VIF value of all independent variables is also smaller than 10 so that there is no correlation symptom in independent variable. So it can be concluded that there is no symptom of multicollinearity between independent variables in the regression model.

\section{Heteroscedasticity Test}

The heteroscedasticity test aims to test whether from the regression model there is an inequality of variance from the residuals of one observation to another observation. A good regression model is one with homoscedasticity or no heteroscedasticity. One 


\section{The Effect of Price Perception and Game Features in Online Virtual Game Item Purchase Decisions}

way to detect the presence or absence of heteroscedasticity is the Glejser test, in the Glejser test, if the independent variable is statistically significant in influencing the dependent variable, then there is an indication of heteroscedasticity. On the other hand, if the independent variable is not statistically significant in influencing the dependent variable, then there is no indication of heteroscedasticity. This is observed from the significance probability above the $5 \%$ confidence level (Ghozali, 2016; 138).

The results of data processing using SPSS 17.00 show the results in the following table:

Table 6. Glejser Test Results

Coefficients $^{\mathrm{a}}$

\begin{tabular}{|l|l|l|l|l|l|}
\hline \multirow{2}{*}{ Model } & \multicolumn{2}{|l|}{ Unstandardized Coefficients } & Standardized Coefficients & & \\
\cline { 2 - 5 } & $\mathrm{B}$ & Std. Error & Beta & $\mathrm{t}$ & Sig. \\
\hline 1 (Constant) & 1.419 & 3.017 & & .470 & .641 \\
PRICE PERCEPTION & -.079 & .369 & -.043 & -.214 & .832 \\
FITUR GAME & .104 & .206 & .102 & .503 & .618 \\
\hline
\end{tabular}

a. Dependent Variable: ABS_RES

Table 6 shows the significance value of the Price Perception variable (X1) of 0.832 and the Game Feature variable (X2) of 0.618 , both of which are greater than 0.050 so it can be concluded if there are no symptoms of heteroscedasticity.

\section{Multiple Linear Regression Test}

Multiple linear regression testing explains the role of Price Perception Variable (X1) and Game Feature variable (X2) on Purchase Decision Variable (Y). Data analysis in this study used multiple linear regression analysis using SPSS 17.00 for windows. The analysis of each variable is described in the following description:

\section{Table 7. Multiple Linear Regression Results}

Coefficients $^{\mathrm{a}}$

\begin{tabular}{|l|l|l|l|}
\hline \multirow{2}{*}{ Model } & \multicolumn{2}{|l|}{ Unstandardized Coefficients } & Standardized Coefficients \\
\cline { 2 - 4 } 1 & B & Std. Error & Beta \\
PRICE PERCEPTION & -1.318 & 4.863 & \\
FITUR GAME & .534 & .595 & .162 \\
\hline
\end{tabular}

a. Dependent Variable: BUYING DECISION

Based on these results, the multiple linear regression equation has the formulation: $\mathbf{Y}=\mathbf{a}+\mathbf{b} \mathbf{1 X} \mathbf{1}+\mathbf{b} \mathbf{2} \times \mathbf{2}+$, so that the equation is obtained: $\mathbf{Y}=\mathbf{- 1 . 3 1 8}+\mathbf{0 . 5 3 4 X 1}+\mathbf{0 . 6 3 3 \times 2}$.

The description of the multiple linear regression equation above is as follows:

a. The constant value (a) of -1.318 indicates the size of the Purchase Decision variable (Y) if the Price Perception variable (X1) and the Game Features variable (X2) are equal to zero.

b. The regression coefficient value of Price Perception Variable (X1) (b1) of 0.534 indicates the magnitude of the role of Price Perception Variable on Purchase Decision Variable (Y) with the assumption that Game Features variable (X2) is constant. This means that if the Price Perception variable factor $(X 1)$ increases by 1 unit value, it is predicted that the Purchase Decision variable (Y) will increase by 0.534 unit value assuming the Game Features variable (X2) is constant.

c. The value of the regression coefficient for the Game Features variable (X2) (b2) of 0.633 indicates the magnitude of the role of the Game Features variable $(\mathrm{X} 2)$ on the Purchase Decision variable $(\mathrm{Y})$ with the assumption that the Price Perception variable (X1) is constant. This means that if the Game Feature variable factor (X2) increases by 1 unit value, it is predicted that the Purchase Decision variable $(Y)$ will increase by 0.633 unit value assuming the Price Perception Variable $(\mathrm{X} 1)$ is constant. 


\section{The Effect of Price Perception and Game Features in Online Virtual Game Item Purchase Decisions}

\section{Coefficient of Determination (R2)}

The coefficient of determination is used to see how much the independent variable contributes to the dependent variable. The greater the value of the coefficient of determination, the better the ability of the independent variable to explain the dependent variable. If the determination (R2) is getting bigger (closer to 1 ), it can be said that the influence of the $X$ variable is large on the Purchase Decision variable $(\mathrm{Y})$.

The value used to see the coefficient of determination in this study is in the adjusted $R$ square column. This is because the adjusted $R$ square value is not susceptible to the addition of independent variables. The value of the coefficient of determination can be seen in Table 8 below:

\section{Table 8. Coefficient of Determination}

Model Summary

\begin{tabular}{|l|l|l|l|l|}
\hline \multicolumn{1}{|l|}{} & & & & \\
Model & R & R Square & Adjusted R Square & Std. Error of the Estimate \\
\hline 1 & $.457^{\mathrm{a}}$ & .209 & .165 & 3.33995 \\
\hline
\end{tabular}

a. Predictors: (Constant), FITUR GAME, PRICE PERCEPTION

b. Dependent Variable: BUYING DECISION

Based on table 8 , it can be seen that the adjusted $\mathrm{R}$ square value is 0.165 or $16.5 \%$. This shows that the Price Perception Variable and Game Feature Variable can explain the Purchase Decision Variable (Y) of 16.5\%, the remaining $83.5 \%$ (100\% - 16.5\%) is explained by other variables outside this research model such as brand image in this case the image of online games and developer companies, word of mouth, and promotion of the online game.

\section{Hypothesis testing}

\section{1. $\mathbf{t}$ test (Partial)}

The $t$ statistic test is also known as the individual significance test. This test shows how far the influence of the independent variable partially on the dependent variable. In this study, partial hypothesis testing was carried out on each independent variable as shown in Table 9 below:

Table 9. Partial Test (t)

\section{Coefficients $^{\mathrm{a}}$}

\begin{tabular}{|c|c|c|c|c|c|}
\hline \multirow[b]{2}{*}{ Model } & \multicolumn{2}{|c|}{ Unstandardized Coefficients } & \multirow{2}{*}{\begin{tabular}{|l|} 
Standardized Coefficients \\
Beta
\end{tabular}} & \multirow[b]{2}{*}{$T$} & \multirow[b]{2}{*}{ Sig. } \\
\hline & B & Std. Error & & & \\
\hline 1 (Constant) & -1.318 & 4.863 & & -.271 & .788 \\
\hline PRICE PERCEPTION & .534 & .595 & .162 & .896 & .376 \\
\hline FITUR GAME & .633 & .332 & .345 & 1.908 & .064 \\
\hline
\end{tabular}

a. Dependent Variable: PURCHASE DECISION

a. Hypothesis Testing the Effect of Price Perception Variable (X1) on the Virtual Online Game Item Purchase Decision Variable $(Y)$

The form of hypothesis testing based on statistics can be described as follows:

Decision Making Criteria:

1) Reject the hypothesis if tcount $<$ ttable or -tcount $>-$ ttable or Sig value. $>0.05$

2) Accept the hypothesis if tcount ttable or -tcount - ttable or Sig. $<0.05$

From table 4.11, the tcount value is 0.896 . With $=5 \%$, ttable $(5 \% ; n-k=39-2=37)$ the ttable value is 2.026192 . From this description it can be seen that tcount $(0.896)<$ ttable $(2.026192)$, as well as the significance value of $0.376>0.05$, it can be concluded that the first hypothesis is rejected, meaning that the Price Perception variable (X1) has no effect on the Purchase Decision Variable ( $Y$ ). The results of this study are not in accordance with the results of research conducted by Bastian, \& Penny 


\section{The Effect of Price Perception and Game Features in Online Virtual Game Item Purchase Decisions}

Rahmawaty (2016) The Influence of Character Competence, Price Perception, and Game Satisfaction on Purchase Intentions of Virtual Items in the Online Game "DOTA II" the results of the t test for the variable character competence are obtained tcount value of 6.365 with a significance value of $0.000<0.05$ the regression coefficient has a positive value of 0.581 , while the results of the t-test for the Price Perception variable obtained a t-count value of 3.083 with a significance value of $0.003<0.05$ the regression coefficient has a positive value of 0.225 , while the results of the t-test for the game satisfaction variable obtained a tcount of 3.613 with a significance value of $0.000<0.05$, proving that Price Perception has a positive and significant influence on players in the Virtual Item Purchase Intention of Online Game.

b. Hypothesis Testing the Effect of Game Feature Variables (X2) on Online Game Item Virtual Purchase Decision Variables (Y)

The form of hypothesis testing based on statistics can be described as follows:

Decision Making Criteria:

1) Reject the hypothesis if tcount $<$ ttable or -tcount $>$ - ttable or Sig value. $>0.05$

2) Accept the hypothesis if tcount ttable or -tcount - ttable or Sig. $<0.05$

From table 4.11 , the tcount value is 1.908 . With $=5 \%$, ttable $(5 \% ; n k=39-2=37)$ obtained a ttable value of 2.026192 . From this description it can be seen that tcount $(1.908)<$ ttable $(2.026192)$, and the significance value is $0.064>0.05$, it can be concluded that the second hypothesis is rejected, meaning that the Game Feature Variable (X2) has no effect on the Purchase Decision Variable (Y). The results of this study are not in accordance with the results of research conducted by Aditya Yessika Alana, Wahyu Hidayat, and Handoyo Djoko W (2011). The Influence of Brand Image, Design, and Features on Nokia Mobile Phone Purchase Decisions (a case study of Diponegoro University students). From the research results, it is known that brand image has a positive effect, which means that any major changes to brand image will affect purchasing decisions for Nokia products, this is indicated by a regression coefficient of 0.583 . In addition, product design has a significant positive effect, this is indicated by a regression coefficient of $\mathbf{0 . 4 8 4}$, and for product features a significant positive effect on purchasing decisions, with a regression coefficient of 0.798 .

\section{Test F (Simultaneous)}

This test basically shows whether all the independent variables included in this model have a joint effect on the dependent variable. The results of the $F$ test can be seen in the following table 10:

Table 10. Simultaneous Test Results (F)

ANOVA $^{\mathrm{b}}$

\begin{tabular}{|ll|l|l|l|l|l|}
\hline Model & & Sum of Squares & Df & Mean Square & F & Sig. \\
\hline 1 & Regression & 106.001 & 2 & 53.001 & 4.751 & $.015^{\mathrm{a}}$ \\
& Residual & 401.589 & 36 & 11.155 & & \\
& Total & 507.590 & 38 & & & \\
\hline
\end{tabular}

a. Predictors: (Constant), FITUR GAME, PERSEPSI HARGA

b. Dependent Variable: KEPUTUSAN PEMBELIAN

The form of hypothesis testing based on statistics can be described as follows:

Decision Making Criteria:

a) The hypothesis is accepted if the calculated $\mathrm{F}$ value $>\mathrm{F}$ table or Sig. $<0.05$

b) The hypothesis is rejected if the calculated $\mathrm{F}$ value $<\mathrm{F}$ table or Sig. $>0.05$.

From table 4.12 , the Fcount value is 4.751 . With $=5 \%$, dk numerator: 2 , dk denominator: $39-2-1$ (5\%; $2 ; 36)$ obtained Ftable value of 3.26. From the description it can be seen that Fcount $(4,751)>$ Ftable $(3,26)$, and a significance value of $0.015<$ 0.05 , it can be concluded that the third hypothesis is accepted, meaning that the Price Perception Variable (X1) and the Game Feature Variable (X2) have a joint (simultaneous) effect on the Variable Purchase Decision (Y).

\section{CONCLUSION}

This study tries to answer the problem, namely to find out how the influence of Price Perception and Game Features on Virtual Game Item Purchase Decisions. The results of hypothesis testing using multiple linear regression analysis with three independent variables and one dependent variable indicate that:

1. The Price Perception Variable is not a factor in influencing the Online Game Virtual Purchase Decision. This is evidenced from table 4.11, it can be seen if the tcount value is 0.896 or less than ttable ( $\alpha$ : $5 \%, d f: 37=2.026192$ ), besides the 


\section{The Effect of Price Perception and Game Features in Online Virtual Game Item Purchase Decisions}

significance value is 0.376 or greater than the model significance value of 0.05 . Then the results of the hypothesis $\mathrm{H} 1$ are rejected, : Price perception has no effect on the Purchase Decision of Virtual Online Game Items.

2. Game Feature Variable is not one of the factors in influencing the Online Virtual Game Purchase Decision. This is evidenced from table 4.11 , it can be seen if the tcount value is 1.908 or smaller than ttable $(5 \%, \mathrm{df}: 37=2.026192)$, but the significance value is 0.064 or greater than the model significance value of 0.05 . Then the results of the $\mathrm{H} 2$ hypothesis are rejected, meaning that Game Features have no effect on Online Game Item Virtual Purchase Decisions.

3. Perception of Price and Game Features can affect the Decision to Purchase Virtual Items Online Game when used simultaneously, this can be seen from table 4.12 obtained Fcount value of 4.751 or greater than the value of Ftable ( $\alpha$ : $5 \%$, dk numerator : 2, dk denominator: 39-2-1, Ftable: 3.26), and a significance value of 0.015 or less than the model's significance (0.05), it can be concluded that if $\mathrm{H} 3$ is accepted, it means that price perception and game features simultaneously influence the decision. Purchase Virtual Items Online Game.

\section{BIBLIOGRAPHY}

1) Etta Mamang Sangadji, and Dr. Sopiah, 2013 "Consumer Behavior Practical Approach Accompanied by Association of Research Journals" Yogyakarta: CV. Andi Offset.

2) Ghozali. 2016. Application of Multivariete Analysis With IBM SPSS Program. Semarang: Diponegoro University Publishing Agency.

3) Kotler, Phillip. \& Kevin Lane Keller. 2010. "Marketing Management" Jakarta: Erlangga.

4) Kotler, Philip and Kevin Lane Keller, 2011. "Marketing Management", Edition 13. Volumes 1 and 2, Translated by Bob Sabran, Erlangga, Jakarta.

5) Prof.Dr. Sugiyono. 2017. "Business Research Methods (Quantitative, Qualitative, and R\&D Approaches)" Jakarta: CV. Alphabet.

6) Tjiptono, Fandy. 2019. "Marketing Strategy 4th Edition". Yogyakarta: ANDI.

7) Bastian, 2015. The Effect of Character Competence, Virtual Item Value and Game Satisfaction on Intention to Purchase Virtual Items in the "Dota II" Online Game. Indonesian Journal of Management and Business 2015.

8) Febrianto, W. K., and Yessy Artanti 2019. The Effect of Consumption Value on Purchase Intention of Virtual Hero Costume Items. Journal of Management Science Volume 7 Number 2 (2019). Surabaya State University, Surabaya.

9) Guo, Y., and Barnes, S.J. 2012. "Explaining purchasing behavior within world of warcraft." Journal of Computer Information Systems. Vol. 52(3), pp. 18-30.

10) Hamari, J. and Lehdonvirta, V. 2010. "Game design as marketing: how game mechanics create demand for virtual goods." Journal of Business Science and Applied Management. Vol. 5, pp. 14-29.

11) Permitasari, Hutami. 2016. The Effect of Brand Image, Features, and Price Perception on Purchase Decisions (Study on Xiaomi Smartphone Consumers in DIY). Yogyakarta University, Yogyakarta

12) Pratama, Alvin Wahyu Shidiq., Achmad Fauzi DH., and Inggang Parwangsa Nuralam. 2018. The Influence of Consumption Value on Purchase Decisions. Journal of Business Administration (JAB) Vol.61 No. August 2, 2018.

13) Prasetya, Dimas. 2016. The Influence of Price Perception, Product Features and Word of Mouth on Android Smartphone Purchase Decisions. Yogyakarta State University, Yogyakarta

14) Wahyu, A S P, Achmad Fauzi Dh, Inggang Perwangsa Nuralam (2018). "The Influence of Consumption Value on Purchase Decisions (Survey of Active Undergraduate Students 2014/2015, 2015/2016, 2016/2017, and 2017/2018 Business Administration Study Program, Department of Business Administration, Faculty of Administrative Sciences, Universitas Brawijaya)". Brawijaya University, Palembang.

15) https://davidmullich.com/2018/08/06/game-mechanics-vs-game-features/ . Retrieved 11 November 2019.

16) https://chikhungunya.wordpress.com/2011/05/26/definisi-game-dan-type-types/ . Retrieved January 15, 2020.

17) https://ejournal3.undip.ac.id/index.php/jiab/article/view/2193 . Retrieved On February 22, 2020.

18) http://eprints.undip.ac.id/23755/1/M_Rhendria_Dinawan.pdf. Retrieved On February 21, 2020.

19) https://newzoo.com/wp-content/uploads/2019/12/Indonesia_infographic.png. Accessed May 31, 2020.

20) https://repository.widyatama.ac.id/xmlui/bitstream/handle/123456789/7708/Bab\%202.pdf?sequence=10 . Retrieved 27 February 2020.

21) https://www.hestanto.web.id/decision-belian/ . Retrieved January 30, 2020.

22) http://www.martinrecords.com/game/penting-untuk-known-history-perkembangan-game-dan-type/, Accessed December 23, 2019. 


\section{The Effect of Price Perception and Game Features in Online Virtual Game Item Purchase Decisions}

23) https://www.viva.co.id/indepth/sorot/1024018-facts-dan-data-game-online . Retrieved December 11, 2019.

24) http://webcache.googleusercontent.com/search?q=cache:xLbIY97MIT8J:eprints.undip.ac.id/45177/1/03_IDRIS.pdf+\&c $d=3 \& h l=i d \& c t=c \mid n k \& g l=i d \& c l i e n t=f i r e f o x-b-d$. Retrieved December 11, 2019.

25) http://webcache.googleusercontent.com/search?q=cache:hMCjUQH2HOsJ:repository.upi.edu/29575/6/S_PEM_13061 02_Chapter3.pdf+\&cd=5\&hl=en\&ct=clnk\&gl=id\&client=firefox-b-d . Retrieved 11 December 2019.

26) http://webcache.googleusercontent.com/search?q=cache:EvHuxtAzhqgJ:repository.unpas.ac.id/30399/7/BAB\%2520III. $p d f+\& c d=1 \& h l=e n \& c t=c l n k \& g l=i d \& c l i e n t=f i r e f o x-b-d$. Retrieved December 11, 2019.

27) http://webcache.googleusercontent.com/search?q=cache:dFT1NVGgzeMJ:repository.upi.edu/13280/6/S_PEK_100577 6_Chapter3.pdf+\&cd=5\&hl=en\&ct=clnk\&gl=id\&client=firefox-b-d . Retrieved December 11, 2019.

28) https://www.academia.edu/43004122/BAB_I_Tanpa_Pembahan. Accessed March 23, 2020.

29) https://www.zonareference.com/pengertian-value/ . Retrieved On February 15, 2020. 